\title{
Revisiting environmental concern: the role of the United Nations in development management
}

\author{
Santanu Rakshit ${ }^{1}$ \\ Visva-Bharati University, India
}

\begin{abstract}
The intervention of global capital through primitive accumulation is causing immense economic and ecological suffering, particularly among the poorer areas of the less-developed world. The United Nations has taken various actions in the less-developed regions of the world to deal with these concerns and at the same time to obtain a balance between the environment and the market or capital. This article explores the role of UN in administering the resulting environmental crisis through a process of 'development management' which is more about consolidating 'governmentality' in the developing world than reaching a solution to the poverty and environmental destruction driven by capital.
\end{abstract}

Key Words: neoliberal capital; governmentality; primitive accumulation; environmental concern; development management; United Nations

\section{Résumé}

L'intervention de la capitale mondiale grâce à l'accumulation primitive est à l'origine d'immenses souffrances économique et écologique, en particulier parmi les régions les plus pauvres du monde, les moins développés. Les Nations Unies ont pris diverses mesures dans les régions les moins développées pour faire face à ces préoccupations et en même temps d'obtenir un équilibre entre l'environnement et le marché ou de la capitale. Cet article explore le rôle des Nations unies dans l'administration de la crise environnementale résultant à travers un processus de «gestion du développement» qui est plus orienté vers la consolidation de «gouvernementalité» dans le monde en développement que de parvenir à une solution à la pauvreté et destruction de l'environnement entraînée par le capital.

Mots clés: Capital néolibéral; gouvernementalité; accumulation primitive; préoccupation environnementale; gestion du développement; Nations Unies

\section{Resumen}

La intervención del capital globalizado por medio de la accumulacion primitive causa inmensa sufrimiento economico y ecologico, en particular en las areas mas pobres del mundo menos desarrollado. Las Naciones Unidas ha tomado varias acciones en estas áreas del mundo menos desarrollados para confrontar a estas problemas y a la vez llegar a un balance entre el medioambiente y el mercado, o capital. Este articulo explora el papel que juega la ONU en administrar el resultante crisis ecológica por medio de un proceso de "manejo del desarrollo", que suele ser dirigido mas a la consolidación de la "gubernamentalidad" en las áreas menos desarrolladas, que al objetivo de llegar a una solución al problema de pobreza y destrucción ambiental impulsado por capital.

Palabras Claves: Capital neoliberal; gubernamentalidad; accumulacion primitiva; manejo de desarrollo; Naciones Unidas

\footnotetext{
${ }^{1}$ Dr. Santanu Rakshit, Associate Professor, Department of Social Studies and Rural Development/Palli Charcha Kendra, Visva-Bharati University, Santiniketan, West Bengal 731236, India. Email: antanu.rakshit "at" visva-bharati.ac.in. I sincerely acknowledge the constructive and material help provided by my colleagues in the Department of Political Science, MGM College, West Bengal, India and JPE editors and referees.
} 


\section{Introduction}

For most of the last century, issues of the environment and industrial development were considered in isolation, and were assumed to have minimal association. In the twenty-first century, however, we find growing emphasis by international agencies such as the United Nations (UN) towards establishing a balance between environmental protection and industrial development. The UN seeks to create an economic climate in which industrial development does not disrupt the ecological balance, and environmental concerns do not stifle the developmental aspirations of developing economies. Major environmental issues have moved firmly to the center-stage of international politics and have been given utmost importance by the UN. The key questions concerning this process are: 1) whether the UN and like-minded institutions are really serious about striking this balance between industrialisation and environmental protection; and 2) whether the UN's concern over environmental protection and the ecological balance is actually a call for 'development management.'

It is clear that the primary agenda of the UN has been the fulfillment of the economic objectives of the developed economic regions (DR). Nevertheless, the economic agenda of the Less Developed Regions (LDRs) needs to be addressed due to the immiserization and impoverishment that has resulted from the expansion of global capital in the neoliberal moment. The intervention of neoliberal capital for surplus extraction through primitive accumulation has caused immense suffering among the poor in the LDRs (Harvey 2003, 2005). ${ }^{2}$ Logically, to pursue this agenda the UN requires the confidence of the developed countries (DC), which are the main financial contributors of the aid required to manage the socioeconomic crisis generated by this form of accumulation. However, the temporary solace of aid from the DRs is contingent upon continued access of capital to vulnerable social sectors in the LDRs, which results in a destructive process of primitive accumulation (Sanyal 2007).

'Development management' is the term given by Kalyan Sanyal (2007) to Foucault's (1991) concept of 'governmentality', in the specific case where the surplus accumulation process resembles primitive accumulation (Sanyal 2007). This concept has much to offer to discussions in political ecology. In a setting where exploitation and aid are linked, capital manages the contradictions of development in part through a cultural process that constitutes governmentality. As Arturo Escobar states:

The resignification of nature as environment; the reinscription of the earth into capital via the gaze of science; the reinterpretation of poverty as an effect of destroyed environments; the destruction of vernacular gender and the concomitant proletarianization and rearticulation of women's subordination under modern principles; and the new lease on management and planning as arbiters between people and nature, all these are effects of the discursive construction of sustainable development (Escobar 1996: 340).

Sending and Neumann (2006) also locate power inside and outside of the state, and they capture capital's discursive dynamics in the move from governance to governmentality. Similarly, Fletcher (2010) proposes the concepts of 'neoliberal governmentality' and 'neoliberal environmentality' to explain the process of governance and governmentality as it operates from the regional to the global level institutions such as the United Nations, the World Trade Organization, the International Monetary Fund and the World Bank. Similar to Fletcher's approach, this article places the concept of 'governmentality' in a neoliberal framework. Fletcher seems less interested in particularising the accumulation process. I follow Sanyal (2007) in arguing that what sustains 'governmentality' or 'development management', is primitive accumulation in the LDRs. This point has been recognized by Noel Castree, whose concept of the "neo-liberalization of Nature" emphasizes the consequences of accumulation of neoliberal capital in the LDRs through the exploitation of natural resources. Castree opines "...that, in a capitalist world, attempts to neo-liberalize nature can be understood as 'environmental fixes' that are, in theory at least, 'rational' for private producers and also the

${ }^{2}$ Three interrelated aspects of the process of primitive accumulation of surplus can be identified in Marx (1954): i) accumulation of money by merchants; ii) conversion of accumulated money into capital (the means of production) and transformation of direct producers into free wage labourers; iii) creation of an external market for products produced under the capitalist mode of production. 
state (as a key regulator of human - environment interactions)" (Castree 2008). The specific character of that accumulation process remains unclear. The accumulation of global capital through rampant extraction of natural resources has deleterious effects on the environment, and the change in consumption patterns driven by the realization of surplus through mindless overproduction is compounding the problem.

The UN has remained largely passive in ameliorating the political contradictions that surface due to the exercise of economic hegemony of global capital within and between the countries of the LDR. Interestingly, the UN's concern for environmental degradation has itself become an important arena for market intervention. That is to say, nature too is becoming commodified, and becoming an active source of accumulation. Thus, capital's discursive work has appropriated 'nature' and 'environment' in such a way that both have become booming sites of accumulation. Jackson and Victor (2011) demonstrate how technology, work-time reduction and structural economic change all have a part to play in 'innovation economics' and the achievement of carbon management (and other environmental) targets. In the same vein, the UN (2012) also promotes the concept of the economic valuation of nature and environment by supporting offsets, where efforts are made to replace or substitute environments or territories lost to development. Jutta Kills (2014) argues against this approach, showing that the creation of biodiversity markets leads to the financialization of forests, wetlands, peatlands, rivers and other natural places, and the valorized placeholders of 'ecosystem services' become tradable assets in the arena of primitive accumulation.

Furthermore, the idea that making companies pay for the destruction they cause is better than nothing seems to ignore the very politics of power and motivations driving the development of biodiversity banks and green trading exchanges like the 'Bolsa Verde Rio.' On the contrary, it advocates a cynicism that is of little help to movement-building for social and environmental justice. Kills also criticizes vehemently the conservation groups supporting compensation through offsets (Kills 2014). She condemns the move in the application of innovation economics from 'biodiversity offsets', to 'valuation of nature' and the 'financialization of nature.' The way that the UN has shifted the focus to the LDRs and linked the development agenda to environmental concerns suggests that it is really development management, rather than the environment, that is the raison d'être behind such active intervention.

\section{The institution-building process of the UN: from Stockholm to Rio}

The second section of this article outlines the institution building process of the UN. I trace the steps undertaken by the U.N. to resolve the contradiction emanating from the differences in the economic and political considerations of developed and less developed regions, and more importantly, show how these steps actually reflect a process of development management that addresses the crisis emerging from the primitive accumulation of capital (Foucault 1990; Sanyal 2007).

\section{The Stockholm Conference (1972)}

The Stockholm Conference is often considered to be the first important event in the history of modern environmental consciousness. The conference adopted a preamble, 26 principles and an action plan for the human environment (UN 1972). The conference was very significant because, first, it formally recognised the importance of environmental concerns at the national level and transformed them into an international political issue. Second, it bridged, for the first time, the concerns related to environment and development and stressed their inseparability. Third, Stockholm gave active support to the development of national environmental policies, leading to the creation of various national agencies and ministries. Last, the NGOs that participated in the conference later contributed significantly to raising environmental consciousness worldwide. Careful analysis of the Declaration, however, shows how differing priorities of the DR and the LDR (or broadly North and South) were institutionalised by the UN. The Conference signalled the beginning of the process of development management to ameliorate the tensions arising from the contradiction between the spaces of accumulation and exploitation.

Various concerns were manifested in the conference. First, there were a series of general prescriptive objectives that required no active intervention. These included the issue of human rights, disarmament, environmental education and research; general advice on pollution; safeguards for wildlife habitat and 
natural resources; emphasis on non-renewable resources etc. Second, there were concerns about the sovereignty of nation states, including the right of individual nations to formulate population and resource policies, the issue of cooperation in developing international law regarding matters of rehabilitation and compensation for the sufferers of pollution and environmental damage, and the spirit of cooperation in international matters. Finally, there were contested priorities evolving between the DR and the LDR concerning developmental interventions of the international institutions. The fundamental conclusion reached at the Conference, however, was that environmental protections need not hamper the development process and should be attained by rational and integrated development planning. Besides addressing economic issues like poverty, illiteracy and malnutrition, the development process should concentrate on the environment, and developed regions should provide the financial assistance required for such process.

We see, however, that this conclusion substituted concerns about environment for concerns about development. And it is here that the Foucauldian notion of governmentality is so important in understanding the way that DRs were expected to internalize the governance of economic stress and environmental degradation engendered by the process of rapid accumulation by capital. The economic and environmental problems of the third world were addressed in the Stockholm Conference through development management. Interestingly, the preamble intends to suggest that environmental problems in the LDRs are due to underdevelopment, whereas in the developed countries it is the rapid industrialisation and technological advancement that cause them (UN 1972). Here the fallacy of the arguments is clear. In the LDRs the environmental concern is purposefully superimposed on basic developmental concerns of the DRs, and on the other hand the DRs are allowed to carry on their agenda of accumulation, albeit with environmental cautions. The Stockholm conference marked the introduction of the idea of the pursuance of dichotomised economic agendas: capitalist accumulation for some and developmental management under the cover of environmental concern for others.

\section{United Nations Environment Programme (UNEP)}

The most significant outcome of the Stockholm conference was the establishment of UNEP on December $15^{\text {th }}$, 1972 . With this, the idea and the agenda of development management became ingrained. In the 1970s and 1980s, the UNEP initiated several initiatives on environment and developmental issues. Initially it concentrated on environmental issues related to marine pollution, climate and ozone depletion, as well as the problems emanating from overconsumption, overproduction and exhaustion of non-renewable energy sources by the developed countries. Paradoxically all these economic activities were left to the unbridled caprice of the market regime. The worries of the common people of the DRs related to climate concern, ozone layer depletion etcetera were not addressed. Later, manufacturing activities that were fuelling environmental pollution in the DRs were relocated to the LDRs, which settled to some degree the growing environment concerns in the advanced world. This was a solution focused on symptoms rather than causes, and the origin of the problem of environmental destruction was simply shifted to the LDRs. The greed of the market and its rampant intervention in the LDRs for the extraction of natural resources leading to desertification, displacement of human settlement, a water crisis and many other serious concerns were downplayed and addressed only as developmental concerns. ${ }^{3}$

Many of such UNEP's developmental activities related to the environment remained unnoticed due to the lack of emphasis from the UN itself, and a lack of concern by the market. Nevertheless, the UNEP

\footnotetext{
${ }^{3}$ In regards to developmental issues, UNEP's most significant contribution was perhaps to organise the United Nations Conference on Desertification in Nairobi in 1977. This conference adopted a Plan of Action on 9th September 1977 to combat desertification and to reclaim land by the target year 2000 (UN yearbook 1977). Emphasis was placed on curbing population growth and understanding the social, economic and political factors associated with desertification. The United Nations Sudano-Sahelian office (UNSO) was made responsible for coordinating follow-up action in the Sudano-Sahelian region, and UNEP for the rest of the World. In 1984, partly with UNEP encouragement, the Permanent Inter-State Committee on Drought Control in the Sahel (CILSS), the UNDP and the UNSO announced a four-year drought and desertification control programme for the Sahel. The widespread famine in Africa in 1984-85 helped to increase international interest in desertification. In 1985, the Cairo Programme called for cooperation of African countries to prevent environmental degradation and to move towards continent-wide sufficiency in food and energy (Keesing records, 1989). This raised a vital question: during famines, what is to be prioritised, environmental degradation or food sufficiency?
} 
played some role in highlighting the international water crisis, and participated in the 1977 United Nations conference on water in Argentina. A failure of the UNEP was remarkable regarding the disposal of hazardous wastes; it stood on the sidelines while the LDRs became the dumping ground of the hazardous waste of the DRs. Initially only 39 countries signed the agreement on hazardous wastes, when written consent was required from all of the waste importing countries for its implementation. The later rose to over fifty and The Basel Convention was later signed in 1989 (Kummer Peiry 2010).

The UNEP's most publicised successes were the 1985 Vienna Convention agreement for the Protection of the Ozone Layer, and the 1987 Montreal Protocol on the restriction of the production and consumption of Chloro-Fluro-Carbons (CFC) and Halons. The Vienna Convention was signed by twentyone states besides the European Community (UNEP 1985). The Convention had the central objective of protecting human health and the environment against the harmful effects of human activities that resulted from depletion of the ozone layer. Although it could not fulfil this objective, it was the first step towards using market mechanisms to balance the distribution of environmental goods and bads. UNEP successfully built up a consensus on the issue. In February 1987, the representatives of the major industrialised nations met at Vienna in an attempt to reach an agreement on a freeze of CFC production and its gradual phasing out thereafter. As a result, 56 countries signed the first world-wide agreement in Montreal to freeze their production and consumption of five common types of CFCs to 1986 levels by 1990. For Halons emissions were frozen by 1994 and to be reduced by 2000. The Protocol was able to restrict trade in ozone-harming substances by helping countries to share information about ozone-safe technologies with the objective of protecting the stratospheric Ozone layer (UN 1987). This could happen only if there was a positive market response. The then-Executive Director of United Nation Environment Programme Mostafa Tolba commented that this was the first truly global treaty that offered protection to every single human being. Managing global problems through regional UN actions advanced, with 10 regions and 120 coastal states signed up in 1982, but by 1992 this has increased to nearly 140 countries, 14 UN agencies, and 12 other international organisations involved, resulting in eight international conventions and eighteen protocols and agreements (Adams 1990; McCormick 1995).

Despite these gains, conflict seems to be inherent in the UN's process of institution building. Quite naturally and logically, the heterogeneity across regions in terms of their power, economic controls, and market integration, along with capital's uneven intervention in the global economic sphere, showed itself in the UN's differential focus on environmental issues in DRs and LDRs, and conflicts resulted. In a larger sense the conflicting objectives of the UN regarding environmental concern were meaningless, because the whole sphere of production and accumulation of capital is beyond the control of the UN and UNEP, officially just a small unit of the UN Secretariat. Even the UNEP is severely constrained in carrying out its own projects and fails to persuade other UN agencies to execute programmes. Nevertheless, the conflict between the developmental concerns of developing nations on one hand and the economic domination of DRs on the other, required attention. This perhaps is the reason for the creation of a consensus approach to developmental need in the LDRs, which began with the preparation of World Conservation Strategy (WCS) drawn up by International Union for Conservation of Nature and Natural Resources (IUCN). With the publication of the report in 1980 the much hyped concept of 'sustainable development' surfaced, infused with the essence of governmentality (IUCN 1980). The recommendation of this report was that human activities should be redirected towards a pathway of sustainable development shouldered jointly by all nations. The famous Brundtland report, Our Common Future was squarely lodged in this tendency. ${ }^{4}$

\section{Our Common Future}

The Brundtland Report showed the new vision of developmental intervention in the LDRs in the form of international responsibility towards the management of the population in the margins, that is, the

\footnotetext{
${ }^{4}$ The Brundtland Report resulted from discussions at a special session of UNEP's governing council held in 1982. It concluded with an emphasis on long-term environmental planning. In 1987, at its 43rd session, the General Assembly Commission adopted by consensus the document Environmental perspectives to the year 2000 and beyond, which provided a framework for national and international action to translate the Brundtland Report into practical action (Brundtland 1987).
} 
people excluded from the space of capital accumulation (Brundtland 1987). ${ }^{5}$ Emphasising the relation between environment and development this report re-envisioned the role of the market by prioritising economic inequality and exploitation, and addressing these along with necessary ecological considerations. Nevertheless, the report also contained stereotyped warnings which remained generally unheeded by capitalist economic systems. As mentioned before, many of the activities that were prohibited in DRs had moved by then to the LDRs. In Our Common Future the definition of sustainable development was "development that meets the needs of the present without compromising the ability of future generations to meet their own needs" (Brundtland 1987), an advisory perfectly suited for the DRs yet never to be practised in the LDRs. The concept of sustainable development propagated by this report crystallised with the establishment of UNCED which subsequently took shape in the great 'Earth Summit' that was held in Rio de Janeiro in June, 1992.

\section{Earth Summit}

Rio was the largest international conference ever held, with thirty thousand people attendees and a conflagration of publicity around the world. In the summit most of the heads of the government signed a package of agreements consisting of five documents: the Rio Declaration - a statement of 27 principles to guide national conduct on environmental protection and development; three legally binding documents; a Biodiversity Convention; a Climate Change convention; the Convention to Combat Desertification, and 'Agenda 21' - a massive document of 800 pages presenting a detailed global action plan for sustainable development including goals, responsibilities and estimates for funding to save the planet in the twenty first century (Parson, Haas and Levy 1992). Despite some reservations on the part of the USA, the Convention was finally signed by 155 nations at the Summit.

The Convention on Biological Diversity seems to have emerged as the principle instrument for the achievement of the objectives of sustainable conservation and use of biological resources, as stipulated in Chapter-15 of 'Agenda 21.' Unlike other conventions, it encompassed a wider context for all biological diversity protection as well as sustainable use of the components of biodiversity, and fair sharing of genetic reserves (Chatterjee and Finger 1994: 49). During the following two decades there were several by-products from the Convention on Biodiversity. ${ }^{6}$ Efforts focused on developing binding agreements to protect the overwhelming loss of forests. As usual, the widespread and open opposition by tropical countries hindered the creation of a legally binding agreement. Finally, 17 non-binding Forest Principles were negotiated by the nations in the Rio that explicitly include all types of forests (Forest Principles 1992). However, this consensus concerned the development of sustainable forest management policies. It recognised sovereign rights of nations in maintaining the forests according to their wishes. These countries were also promised financial aid and assistance from the UN for the maintenance. Development management under the aegis of the UN was mooted.

At the Rio-Summit it was generally agreed that responsibility falls upon the developed nations to fight against Climate Change (UNFCC 1992) ${ }^{7}$, as they are mainly responsible for the rapid increase in greenhouse gas concentrations in the atmosphere. In order to develop some positive mechanisms to meet its goals, the signatories or the parties in the Framework Convention agreed to meet annually. The first meeting or 'Conference of Parties' (COP) was held in 1995 in Rome, the second COP was held in Geneva, and the third COP was held in Kyoto, Japan in December 1997 to implement the legally binding agreements on greenhouse gas emissions. The Kyoto Protocol (1997) envisaged action by financially strong nations like

\footnotetext{
${ }^{5}$ In its 383 pages the report stressed that "sustainable human progress can be achieved only through a system of international cooperation which treats environmental protection and economic growth as inseparable." The Telegraph, $6^{\text {th }}$ July, 1987.

${ }^{6}$ These included: the Cartagena Protocol on Biosafety, the Convention on International trade in Endangered Species of Wild Fauna, the Convention on the Wetlands of International Importance and the Convention for the Protection of World Cultural and Natural Heritage. The concept of a Global Forest Convention was first mooted in the report of the Independent review of the Tropical Forestry Action Plan (TEAP) in May 1990. The Food and Agricultural Organisation (FAO) prepared a first rough draft of a forest convention and recommended in November 1990 that a treaty regarding the subject be concluded in time for UNCED.

${ }^{7}$ UN Framework Convention on Climate Change, $9^{\text {th }}$ May 1992, article 2.
} 
the USA with high emission levels. However, due to adamant opposition from the USA, Australia and other industrialised nations, the Protocol indicated that there would be no binding commitments required for developing countries! To the dismay of the LDRs, the United States expressed unwillingness to ratify or be a participant in the Convention, and the Kyoto Protocol suffered a big setback. The USA did not enter into the agreement under the pretext that there was no "meaningful involvement" on the part of the developing nations, and also that it would be detrimental to its economic interest. This despite the fact that, while the USA represents only 4 per cent of the global population, it releases at least 25 per cent of the world's greenhouse gases. The main success of this conference lay in the fact that environment and development were thrust to the fore of the political agendas of every nation, and that the issue of poverty and development was made a central issue.

\section{Institution-building in the post-Rio Summit era}

\section{The Johannesburg Summit}

The post-Rio era seems to be the story of negotiations and effort without success. The goal of resolving conflicting interests and contradictions between the developed and the developing countries, as envisaged in the Brundtland and other reports, was forgotten. Instead the priority shifted to creating a balance between worldwide increasing populations and decreasing natural resources. The Johannesburg Summit or Earth Summit was held in 2002 and aimed at generating a practical programme for the transformation of the dream of sustainable development into reality, and pointing the way towards a new global society that is caring and humane. Among the agreements reached were the Millennium Development Goals, setting many targets to be reached by 2015, including a goal to reduce the proportion of people who lack access to proper sanitation (MDG 2015). There was an agreement to work to increase access to modern energy services and towards increasing the use of renewable energies, as well as a number of targets and timetables aimed at protecting or restoring ecosystems. ${ }^{8}$ Leaders from developing countries stressed that greater international cooperation is necessary to promote Sustainable Development. The United Nations assured financial aid and assistance on the condition that developing countries take necessary initiatives to materialise the programme into action, as mentioned in Agenda 21.

About 99 per cent of the text concerning finance has been agreed upon, and about 80 per cent of the section on trade. In the negotiations there are still several tough issues that are yet to be resolved, such as trade subsidies, globalisation issues, and a target for providing proper sanitation. This shows that the UN's actions have failed to influence the market domain or the sphere of accumulation, and suggests why trade issues have not been resolved. On the other hand, issues concerning finance which lie outside the market domain have been readily agreed upon. In the negotiations regarding finance, countries have agreed to the paragraphs regarding the global environment facility (GEF), which has been furnished to the tune of US\$2.9 billion. There was also an agreement on a provision calling on the GEF to serve as the funding mechanism for the Convention to Combat Desertification, a major issue for African countries. Furthermore, the UNDP announced that it would launch the Global Village Energy Partnership in 2002, a ten-year implementationbased program to catalyse country commitments to village energy production and guide policies and investments. The GVEP has now spun off as a UK registered NGO.

The Johannesburg Summit reflected the UN-led development management strategy for the LDRs. It started by creating partnerships in the five priority areas: water, energy, health, agriculture and biodiversity. All of these areas show deep problems resulting from the vigorous economic intervention of the DRs in the natural space of LDRs. However, the challenge of resolving these problems was forced upon the LDRs, that were asked to focus their attention on how their people can improve their lives and conserve their natural resources. The Summit envisioned the involvement of people from all corners of the world (read LDRs) and from all walks of life (read poorer sections of LDRs): these men and women should be building balanced economic growth, environmental protection and social progress. The Earth Summit was neither new nor

${ }^{8}$ World Summit on Sustainable Development Daily Highlights

http://www.un.org/events/wssd/highlights/020826hilit.htm Retrieved 7/13/15. 
revolutionary in comparison to Rio. The main objectives of environmental concern seem to be the same: development management in the guise of environmental concern.

The Johannesburg Summit also marked a deceleration of the environmental movement in the face of institutional stagnation and other obstacles. Regrettably, twenty-four years after Rio, global environmental conditions are still alarming. Only a few countries, mostly among the DRs, have managed to restrain pollution and control environmental degradation. The only bright spot of this conference seemed to be the agreement on climate change (UNFCC 1992). The fallacies underlying the measures taken by the UN can be seen in the remarks of Kofi Annan and the actions of UN conventions on International Trade. According to Annan, most countries experienced major constraints owing to lack of national capacities resulting from lack of "new and additional financial resources" that were promised at the Rio Summit. Therefore, very few countries managed to restrain the rapid acceleration of species loss. Paradoxically, in 2004 the same UN, in its earlier Convention on International Trade in Endangered Species (CITES 1973), granted permission to South Africa, Botswana and Namibia to sell 60 tons of stockpiled elephant tusks. ${ }^{9}$ In face of this action, the declared concerns for the environment and bio-diversity seemed hollow.

Moreover, the richer economic sectors of the developing countries, to fulfil their desire for enlarged consumption and accumulation of wealth, exerted a hegemonic relation of development management over their poor countrymen that was similar in essence to the hegemonies exercised by DRs on LDRs. This is shown in the understanding reached between the most powerful developed nations like the USA, Japan, and Australia and the growing developing nations like China, Korea and India over technology transfer and partnerships for carbon abatement. The Asia Pacific Partnership on Clean Development and Climate Conference in Sydney, January 2006 established public-private partnership arrangements. India asserted its right to emit carbon, and various green groups hold the view that these talks in Sydney were aimed at subverting the Kyoto Protocol. ${ }^{10}$ Most partnerships expired in 2011, and led by national elites, popular resentment against the economic domination of the heavily industrialised countries weakened.

\section{The Copenhagen, Cancun, and Durban Conventions}

The UN Climate Change Conference in Copenhagen, Denmark, took place in December 2009 with the usual hue and cry over issues of transparency and process. The major economies dominated affairs with high-level sectoral and informal discussions, and it was actually those auxiliary meetings held alongside the main conventions that resulted in the infamous political agreement known as the Copenhagen Accord (2009). By 2010, 140 countries indicated their support, although the exercise was considered largely futile in the context of serious ongoing environmental degradation. However, a convention in Cancun, Mexico in December, 2010 seemed to generate some concrete proposals to mitigate environmental problems. First, Decision 1/CP.16 recognized the need for cuts in global emissions in order to limit the global average temperature rise to $2^{\circ} \mathrm{C}$ above pre-industrial levels. Second, the Green Climate Fund (GCF) was created with a 24-member board, and defined as the operating entity of the Convention's financial mechanism. Parties reiterated the commitment by developed countries to provide US $\$ 30$ billion of fast-start financing in 2010-2012, and to jointly mobilize US\$100 billion per year by 2020.

The conference in Durban, South Africa, held in 2011, dealt with a variety of issues, especially those related to the Kyoto Protocol and GCF. The convention also agreed to launch the new Ad Hoc Working Group on the Durban Platform for Enhanced Action (ADP), and the program of Reducing Emissions from Deforestation and Forest Degradation in Developing countries (REDD+) made three important gains. First, it started a second round of the commitment period for the Kyoto Protocol; second, the Convention decided on long-term cooperative actions, and third, an agreement was reached concerning the operationalization of the GCF. The new ADP was launched with a mandate "to develop a protocol, another legal instrument or an agreed outcome with legal force under the Convention applicable to all Parties", and the ADP is scheduled to complete these negotiations by 2015. The new instrument should enter into effect from 2020 onwards.

${ }^{9}$ Green Hope Vol. 1, March 2003.

${ }^{10}$ The Telegraph, Thursday, $12^{\text {th }}$ Jan, 2006. 
Despite these gains, some feel that the ADP needs to become more focused and interactive in future sessions.

\section{Climate change conferences}

The Bonn Climate Change Conference in 2013 was marred by dispute over legal and procedural issues raised by the Russian Federation, Belarus, Ukraine and others on SBI 38 (Subsidiary Body for implementation). Since no solution was reached, SBI failed to deliver. It seemed to have made good progress on methodological issues although no agreement was reached on establishing a more formal process. Many feel that switching to a negotiation mode would ensure ADP's progress in future session, but it sometimes seems that there is an endless unproductive discussion of terms: "dispute"; "negotiation"; "agreements"; and so on. The Warsaw Climate Change Conference in November of 2013 started with strong rhetoric from Christina Figueres, Secretary of the United Nations Framework Convention on Climate Change, "that it is not a game: we either win or lose." The final statement of the Conference (FCCC/CP/2013/L.13) underlines the urgency of implementing commitments related to finance and technology transfer under the Convention, and reiterates the commitment by developed countries to jointly mobilize US $\$ 100$ billion annually by 2020 . The statement also recognizes the pledges developed countries have made since the Conference of the Parties (COP) 18, and requests that parties enhance their enabling environments and policy frameworks. The Conference urged developed countries to sustain public climate finance at increasing levels from a variety of sources and to channel a substantial share of public funds to adaptation. Developed countries were asked to prepare biennial submissions concerning their strategies and approaches for scaling up climate finance from 2014 until 2020 and include information on quantitative and qualitative elements of this pathway. It also decided to continue deliberations on long-term climate finance (LTF).

Through initiatives like REDD+, ADP, and other outcomes of brainstorming sessions of climate change conventions and conferences mentioned above, the UN actually drew in non-state actors from business and NGOs for monitoring, pointing to an increased neoliberalisation of nature. The promulgation of new agreements hastened the rollback of the state in the interest of neoliberal capital, forcing state-owned capital to take a back seat in the arena of environmental concerns. Private capital and the market mechanism were brought into action for the commoditisation of the environment, a move anticipated and critiqued by numerous scholars and activists (Castree 2008; Fletcher 2010; Kills 2014; Klein 2014; Sending and Neumann 2006).

The main outcomes of the different conferences and conventions reflect the initiation of a perpetual process, with an infinite loop that leads to nowhere. Their agendas and resolutions are essentially the same, whether taken in Stockholm, Rio, Johannesburg, Copenhagen or Cancun. State and non-state actors are expected to concentrate only on development management and leave environmental concerns under the control of capital and its market mechanism (Klein 2014). It is crystal clear that the activities in the market domain or accumulation sphere are the main source of environmental degradation, and if the UN's institutions fail to bridle the market activities of neo-liberal capital, nothing better can be expected.

\section{BRICS and environment initiatives}

It would be a mistake not to mention the environment initiatives of the BRICS countries. The response of this group of countries appears convoluted. According to the Centre for the Study of Governance Innovation (2013):

...the reality appears much more complex than the 'global power shift' discourse would have us believe. First of all, the BRICS countries have little in common in political terms. As many analysts have argued, the "alliance" can be better described as a marriage of convenience rather than a real partnership for change. 
The initial negotiation of the BRICS in the international environmental forums on climate change seemed to be valid. They did not want to commit themselves to the stipulations of the Kyoto Protocol unless the USA also made such a commitment. The USA has made the same argument about the BRICS, what Rafael Leal-Arcas (2013) terms the "circular argument." At times it seems as if USA and the BRICS are in connivance, and playing a coordinated game of Prisoner's Dilemma in order to undermine the effort of the environmentalists and climate change mitigation. To Leal-Arcas, "the BRICS today are amongst the largest GHG polluters in the world. Without their efforts, climate change mitigation will be very difficult in the near future" (2013:4). The same can be said for the USA. China however, has shown some commitment to contribute to climate change mitigation with an aggressive move into renewable energy markets. But Brazil and India are sticking to their old argument, giving the USA an escape route to dishonour the climate change propositions. This spoof on the part of the BRICS and the USA reflects the intention of unabated primitive accumulation accompanied with development management.

\section{Conclusion}

Financial constraints, conflicting objectives and inherent structural contradictions of the different agencies of the UN in the UN programmes appear evident. As a result, all the environmental threats perceived fifty or sixty years ago by the Club of Rome, the Founex Report (1971), or Stockholm (UN 1972) still persist, but with greater ferocity. This is because concerns have always dominated the conferences and summits, hindering the process of creating legal sanctions and making the proceedings a moral covenant to be obeyed by the LDRs only. The process boils down to structural adjustments in LDRs, or containment of environmental concerns through 'development management' as 'sustainable development.'

The reaction of the developing countries or the LDRs not to bind themselves into any legally enforceable commitments seems to be quite justified. The less-developed countries argue that they should not be responsible for redressing a problem that they did not create (anthropogenic climate change and pollution) and argue that they do not possess the necessary wealth and resources to implement protocol agreements. They perceive the demand of the DRs as an attempt to suppress their economic and industrial growth, as LDR citizens are also desperately striving for a better and high standard of life and relying on fossil fuels. ${ }^{11}$ These reactions by LDRs and DRs on issues of environmental concern and economic development converge to a single outcome: non-action on the imminent threat of environmental degradation. It seems capital had successfully manipulated the state and non-state actors of DRs and LDRs to connive in a never-ending loop. In the meantime, market greed and primitive accumulation continues in the LDRs, and the resulting poverty overcomes all environmental concern.

The main obstacle to environmental concern, however, is the dominance of the DRs and the economically richer sections of the LDRs. The UN has failed to confront overconsumption and overproduction among the rich countries and rich economic groups throughout the world, and the environmental destruction this causes. Rapid desertification and drought continued unabated, threatening the livelihoods of more than a billion of people worldwide. The Food and Agriculture Organization (FAO) of the UN has warned that the earth is losing more than seven million hectares of cultivable land every year due to soil degradation. According to the FAO and other international agencies, desertification is a result of over-grazing, destructive agricultural practices and deforestation, all of which have some links to the process of capital accumulation and alienation of land in both of DRs and LDRs. According to Rafael LealArcas writing in Green Hope (2003), and following a fundamental insight by political ecologists, "the biggest environmental problem faced by us is inequality of resource distribution between the haves and have-nots and subsequent overexploitation of local resources despite in many cases an awareness of the unsustainability of such resource use."

The environmental concerns of the DRs have been relocated to the LDRs, which are thus the site of resource exploitation through primitive accumulation. It is thus not surprising why at that time the political leaders of the LDRs became vocal against implementation of the Kyoto Protocol, the first commitment

\footnotetext{
${ }^{11}$ India, for example, has not committed to reducing greenhouse gases, prioritising instead the alleviation of poverty. The argument is that India generates 1 ton of GHGs for every 20 tons produced by the USA.
} 
period of which expired in 2012. Though devoid of any logical explanation given the effects of climate change on their nations, such resistance handsomely vindicates claims of subjugation. The response of the BRICS (except China) follows suit, and it seems that there is no or little future to international climate negotiations forcing considerable emissions reductions on countries still anxious to develop economically. Successful implementation of measures related to environmental preservation is unlikely. Fundamentally this is the story of how capital makes concessions for its unbridled accumulation in the economic spaces of LDRs. Simultaneously, LDRs, trying to preserve their political sovereignty, try to extract concessions from capital to manage their burgeoning 'excluded' populations through forms of development management. The global environment remains an issue of perpetual concern.

\section{References}

Adams W.M. 1990. Green development: environment and sustainability in the Third World. London Routledge. $1^{\text {st }}$ edn.

Brundtland H. 1987. Our common future. Oxford: Oxford University Press, for the World Commission on Environment and Development.

Castree N. 2008. Neoliberalising nature: the logics of deregulation and reregulation. Environment and Planning A. 40(1): 131 - 152.

Centre for the Study of Governance Innovation. 2013. On the BRICS of collapse? Why emerging economies need a different development model. Pretoria: CSGI, University of Pretoria.

Chatterjee P. and Finger M. 1994. The earth brokers: powers, politics and world development. London: Routledge.

CITES 1973. Convention on International Trade in Endangered Species of Wild Fauna and Flora. Geneva: CITES Secretariat.

Copenhagen Accord. 2009. Copenhagen Accord. Geneva: UNFCC.

Escobar A. 1996. Construction nature: elements for a post-structuralist political ecology. Futures 28(4): 325-343.

Fletcher R. 2010. Neoliberal environmentality: towards a poststructuralist political ecology of the conservation debate. Conservation and Society. 8(3): 171-181.

Forest Principles, 1992. Annex III: Non-legally binding authoritative statement of principles for a global consensus on the management, conservation and sustainable development of all types of forests. New York: United Nations.

Foucault M. 1991. 'Governmentality', trans. Rosi Braidotti and revised by Colin Gordon, in Burchell G., C. Gordon and P. Miller (eds.) The Foucault effect: studies in governmentality. Chicago: University of Chicago Press. Pp. 87-104.

Founex Report. 1971. Environment and development: The Founex Report on development and environment. Carnegie Endowment for International Peace.

Green Hope 2003. Volume 1, March 2003. Archived

http://www.indiaenvironmentportal.org.in/category/9306/name_of the journal/green-hope/

Green Hope Volume 2, issue 1, Nov 2003. Archived http://www.indiaenvironmentportal.org.in/category/9306/name of the journal/green-hope/

Harvey D. 2003. The new imperialism. Oxford: Oxford University Press.

Harvey D. 2005. A brief history of neoliberalism. Oxford: Oxford University Press.

IUCN. 1980. World conservation strategy: living resource conservation for sustainable development. Geneva: International Union for Conservation of Nature and Natural Resources.

Jackson T. and Victor P. 2011. Productivity and work in the 'green economy': some theoretical reflections and empirical tests. Environmental Innovation and Societal Transitions 1: 101-108.

Keesing records. 1989. Keesing's record of world events 1989. London: Longman. 
Kills J. 2014. Economic valuation of nature; the price to pay for conservation? A critical exploration. Brussels: Rosa-Luxemburg-Stiftung.

Klein N. 2014. This changes everything: capitalism vs. the climate. New York: Simon and Schuster.

Kyoto Protocol. 1997. Kyoto Protocol. New York: United Nations.

Leal-Arcas R. 2013. The BRICS and climate change. International Affairs Forum 4(1): 1-5.

Marx K. 1954 (1867). Capital, Volume 1. Progress Publishers.

McCormick J. 1995. The global environmental movement. London: Wiley.

MDG 2015. Millennium Development Goals and beyond 2015. New York: United Nations.

Parson E.A., P.M. Haas and M.A. Levy. 1992. A summary of major documents signed at the Earth Summit and the Global Forum. Environment 34 (4): 12-15, 34-36.

Kummer Peiry K. 2010. Introductory note. Basel Convention on the Control of Transboundary Movements of Hazardous Wastes and their Disposal. Nairobi: UNEP.

Sanyal K. 2007. Rethinking capitalist development. London: Routledge.

Sending O.J. and I.B. Neumann. 2006. Governance to governmentality: analyzing NGOs, states, and power. International Studies Quarterly. 50: 651-672.

UNFCC. 1992. UN Framework Convention on Climate Change, 9th May 1992. New York: United Nations.

UN. 1972. Declaration of the United Nations Conference on the Human Environment. Nairobi: UNEP.

UN. 1987. The Montreal Protocol on Substances that Deplete the Ozone Layer. Ozone Secretariat, United Nations.

UN Yearbook. 1977. Yearbook of the United Nations 1977. New York: United Nations.

UNEP. 1985. The Vienna Convention for the Protection of the Ozone Layer. Nairobi: UNEP. 